\title{
Application of Value Engineering to Rework Reduction in Ship Building Project
}

\author{
Dr. Tushar N. Desai ${ }^{1}$, Mr. S. R. Prajapati ${ }^{2}$ and Mr. Hitesh R. Patel $^{3}$ \\ ${ }^{1}$ Associate Professor, Sardar Vallabhbhai National Institute of Technology, Surat, India \\ ${ }^{2}$ Asst. Manager in Shipbuilding Division, Larsen \& Toubro Ltd., Hazira, Surat, India \\ ${ }^{3}$ Asst. Manager, Larsen \& Toubro Ltd., Hazira, Surat, India
}

\begin{abstract}
Value engineering is an organized creative technique to analyze the function of a product or a system for achieving the required function at minimum cost along with required performance, reliability, maintainability, appearance, safety etc. Value engineering has been proved to be a very effective tool of materials management and cost reduction in modern industry. It proceeds with the analysis of the value or the utility of the product and then to investigate as to how the value can be improved or if the part can be eliminated or replaced by any other part of the same value (utility) or lesser cost. The paper presents the application of value engineering to minimize rework in ship construction and reduction of cycle time of a project.

Keywords- Value Engineering, Rework reduction, Ship building project
\end{abstract}

\section{Introduction}

The history of value engineering dated back to World war-II. Mr. Lawrence D. Miles, an American Engineer is considered the "Father of Value Engineering". Mr. Mile worked as purchase engineer at General Electronics (GE) from 1932 to 1947 [1]. Quantitative component of value is the ratio of Function by Cost [2].

In other words, Value $=\frac{\text { Function }}{\text { Cost }}$

Value of the product can be increased without compromising its quality [3].

- Achieve same function at lesser cost

- Achieve a multiple function at lesser cost

- Achieve a multiple function at greater cost.

Figure 1 illustrates design for production how to get more for less.

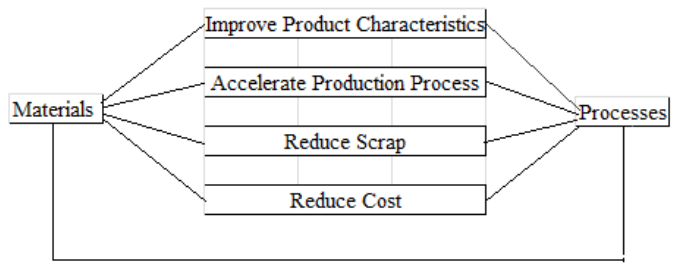

Figure 1.Design for Production How to get more for less [4]

\section{Value engineering tools}

\section{A. Function-Cost-Worth Analysis.}

Function- Cost- Worth analysis (F-C-W Analysis) entails answering following questions:-

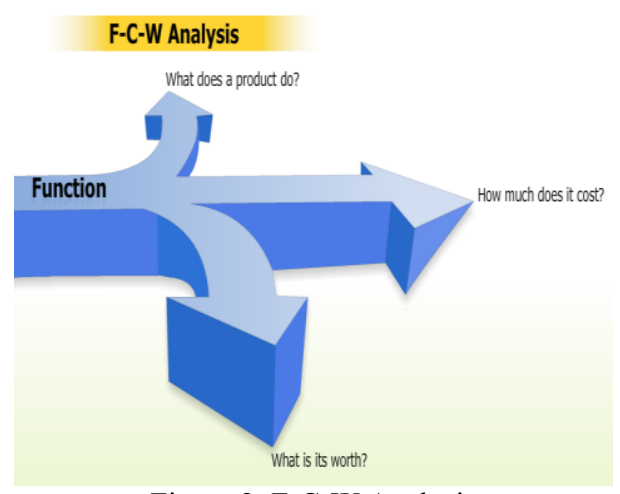

Figure 2. F-C-W Analysis

Figure 2 exhibits F-C-W analysis. Table I illustrates an example of cost allocation; the product in question is a pencil [5].

TABLE I. Cost allocation function

\begin{tabular}{|c|c|c|c|c|}
\hline \multicolumn{2}{|c|}{ Function } & Type & \multicolumn{2}{c|}{ Basis } \\
\hline Verb & Noun & B/S & Elements of cost & Cost (Rs.) \\
\hline Make & Mark & B & Cost of Lead & 0.30 \\
\hline Protect & Lead & S & Cost of Wood & 0.49 \\
\hline Indicate & Specification & $\mathrm{S}$ & Cost of Printing & 0.01 \\
\hline Indicate & Manufacturer & $\mathrm{S}$ & Cost of Printing & 0.02 \\
\hline Enable & Grip & $\mathrm{S}$ & $\begin{array}{c}\text { Cost of Manufacturing } \\
\text { Hexagonal Shape }\end{array}$ & 0.10 \\
\hline Improve & Appearance & $\mathrm{S}$ & Printing on Pencil & 0.25 \\
\hline Total & Product Cost & & & 1.17 \\
\hline
\end{tabular}




\section{B. Function Analysis System Technique (FAST):}

The Function Analysis System technique (FAST) is systematic diagram technique that logically identifies and visually displays the necessary function to accomplish a design purpose [6]. Figure 3 describes technical fast diagram.

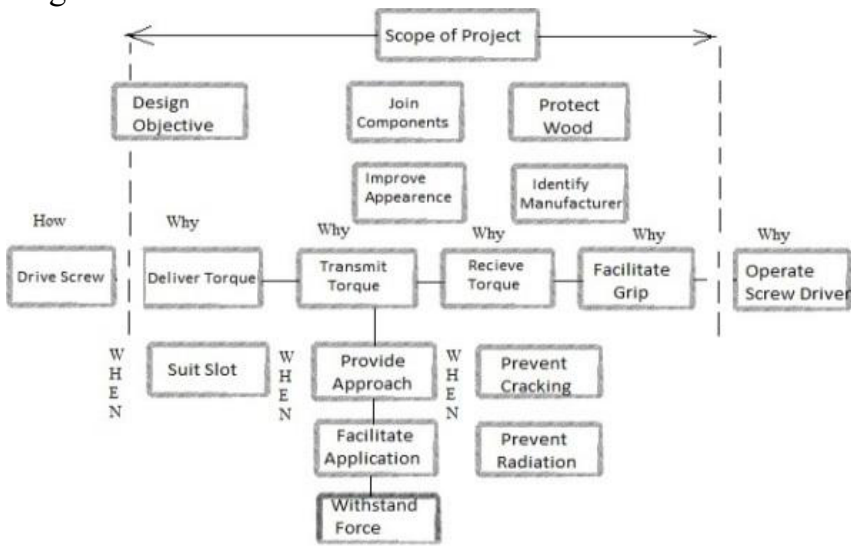

Figure 3. Technical fast Diagram

\section{Case study:-application of value engineering to rework reduction in ship building project}

A case study was carried out for Rework reduction in Hull structure with the help of value engineering.

\section{A. Value Engineering Plan}

It clearly separates analytical from creative operations to assure maximum creative benefit.

Value engineering plan is presented in figure 4.

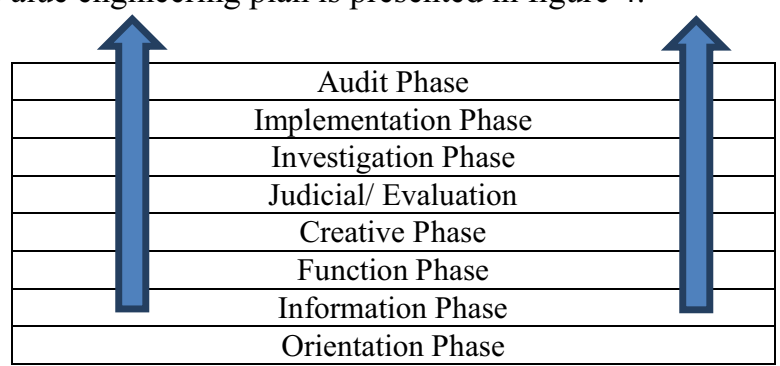

Figure 4. Value Engineering Plan

Figure 5 shows the Roll Dock Ship on trial by Larsen \& Toubro Limited at Hazira works, Surat.

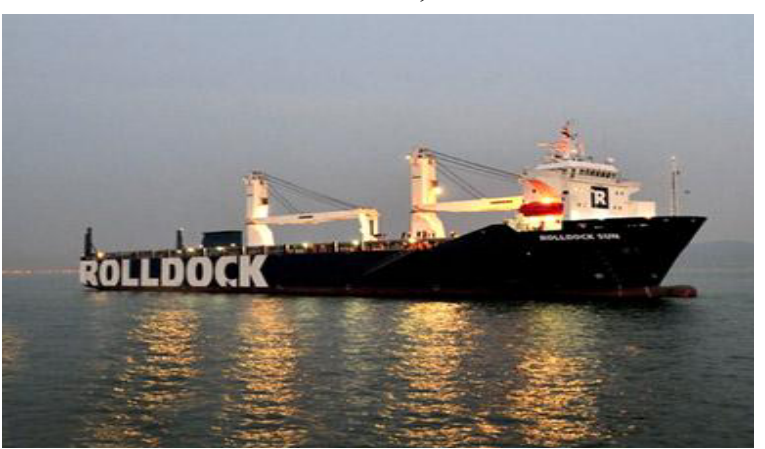

Figure 5. ROLL DOCK SHIP on trial By L\&T Ltd. (Hazira)

\section{B. Ship Block Assembly}

This is known as "block construction". Figure 6 represents the Ship Block assembly.

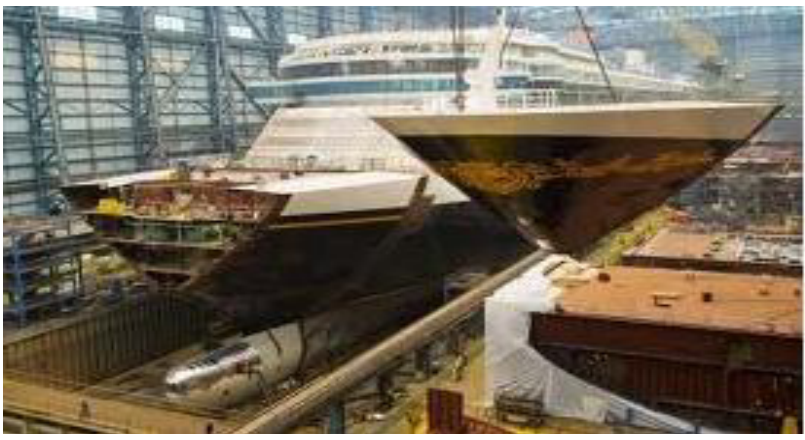

Figure 6. Ship Block Assembly

Figure 7 represents the Ship Block internal structure which consists of Hull out fitting items, electrical machineries and structural parts due to application of value engineering methodology in every item before commencement of the work, lead time and rework are reduced.

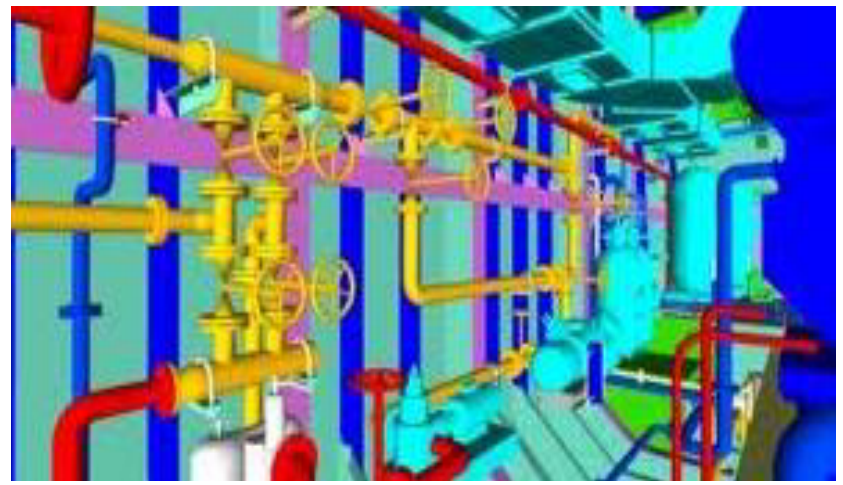

Figure 7. Ship Block Internal Structure

\section{Value Engineering Team Formation}

After finalizing the value engineering plan the next phase includes team formation. The essential team member characteristics include technical or functional expertise, problem solving and decision making abilities and interpersonal skills [7]. Table II represents the team formation.

TABLE II. Team formation table

\begin{tabular}{l}
\hline VE Team Formation Note(2014/2015 VE Project) Date: \\
January 2015 \\
\hline Title: Reduction of Rework on Hull Structure and in Ship by VE \\
Need for VE Project: \\
To reduce Rework and Increase Project Delivery Index \\
\hline Saving target from VE Project \\
\hline Total saving: Rs. $2,34,000 /$ Block \\
Estimated saving in current year: Rs. $2,34,000 * 32=$ Rs. \\
$78,88,000$ \\
\hline The team consists of following members:- \\
Head, Design Team \\
Head, Planning Team \\
Head, Production Management \\
Head, Project Management \\
Head, Accounts \& Finance \\
\hline Team Sponsor \\
\hline Mr. A. Khaitan, GM \\
\hline Team Leader: \\
\hline J. L. Mehta, Head, Production Department \\
\hline
\end{tabular}


Team Members

\begin{tabular}{|c|c|c|}
\hline \multicolumn{3}{|c|}{ Department } \\
\hline Mr. Dinesh Sidhhapara & \multicolumn{2}{|c|}{ Design Team } \\
\hline Mr. Dinesh Prasad & \multicolumn{2}{|c|}{ Planning Department } \\
\hline Mr. Shah & \multicolumn{2}{|c|}{ Finance \& Accounts } \\
\hline Mr. P. K. Bhatt & \multicolumn{2}{|c|}{ Project Management Group } \\
\hline Mr. J. L. Mehta & \multicolumn{2}{|c|}{ Block Assembly } \\
\hline Dr.Tushar N. Desai & \multicolumn{2}{|c|}{ SVNIT, Surat } \\
\hline \multicolumn{3}{|c|}{ VE Co-coordinators: Mr. S. R. Prajapati and Mr. Hitesh R. Patel } \\
\hline \multicolumn{3}{|c|}{ VE Champion : Mr. S. M. Agrawal } \\
\hline \multicolumn{3}{|l|}{ (Team Facilitator) } \\
\hline \multicolumn{3}{|l|}{ VE Auditor } \\
\hline \multirow{3}{*}{\multicolumn{3}{|c|}{$\begin{array}{l}\text { The team is expected to come out with their } \\
\text { recommendations by } 30 / 11 / 2014 \& \text { implementation of } \\
\text { feasible proposals by } 30 / 12 / 2014 \text {. } \\
\text { Frequency of meeting:Fortnightly }\end{array}$}} \\
\hline & & \\
\hline & & \\
\hline \multirow{2}{*}{\multicolumn{3}{|c|}{ CC: Unit Head, Dept. Heads }} \\
\hline & & \\
\hline \multicolumn{3}{|l|}{ Team Leader } \\
\hline \multicolumn{3}{|l|}{ Team Members } \\
\hline \multicolumn{3}{|c|}{ VE Co-ordinator, VE Auditor } \\
\hline VE Champion & & \\
\hline
\end{tabular}

\section{FAST Diagrams}

Figure 8 represents the FAST diagram.

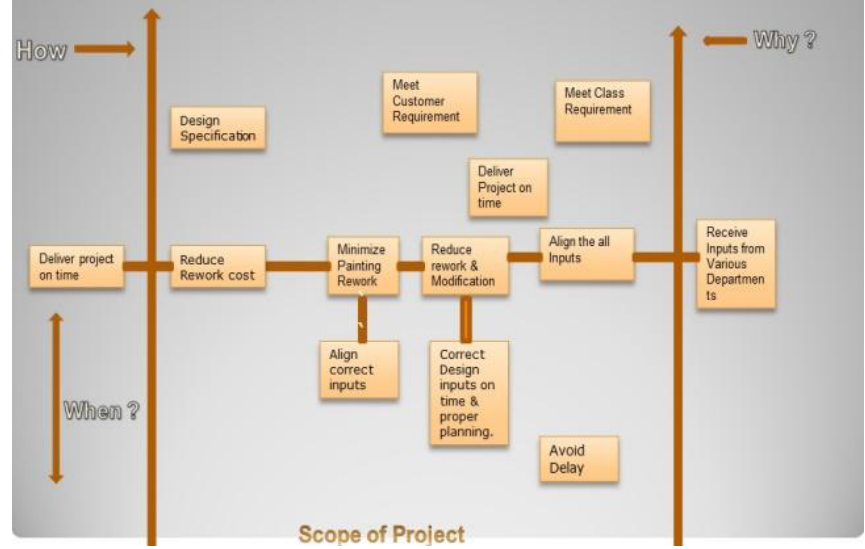

Figure 8. FAST Diagram

\section{E. F-C-W Analysis}

The parameters for value are worth and cost. The worth is the least cost of achieving a function[8]. The function cost worth analysis is a unique tool in value engineering methodology. If used systematically it ensures high benefit to the company as well as achieving better results [9]. Table III represents Function cost worth analysis.

TABLE III. Function cost worth analysis

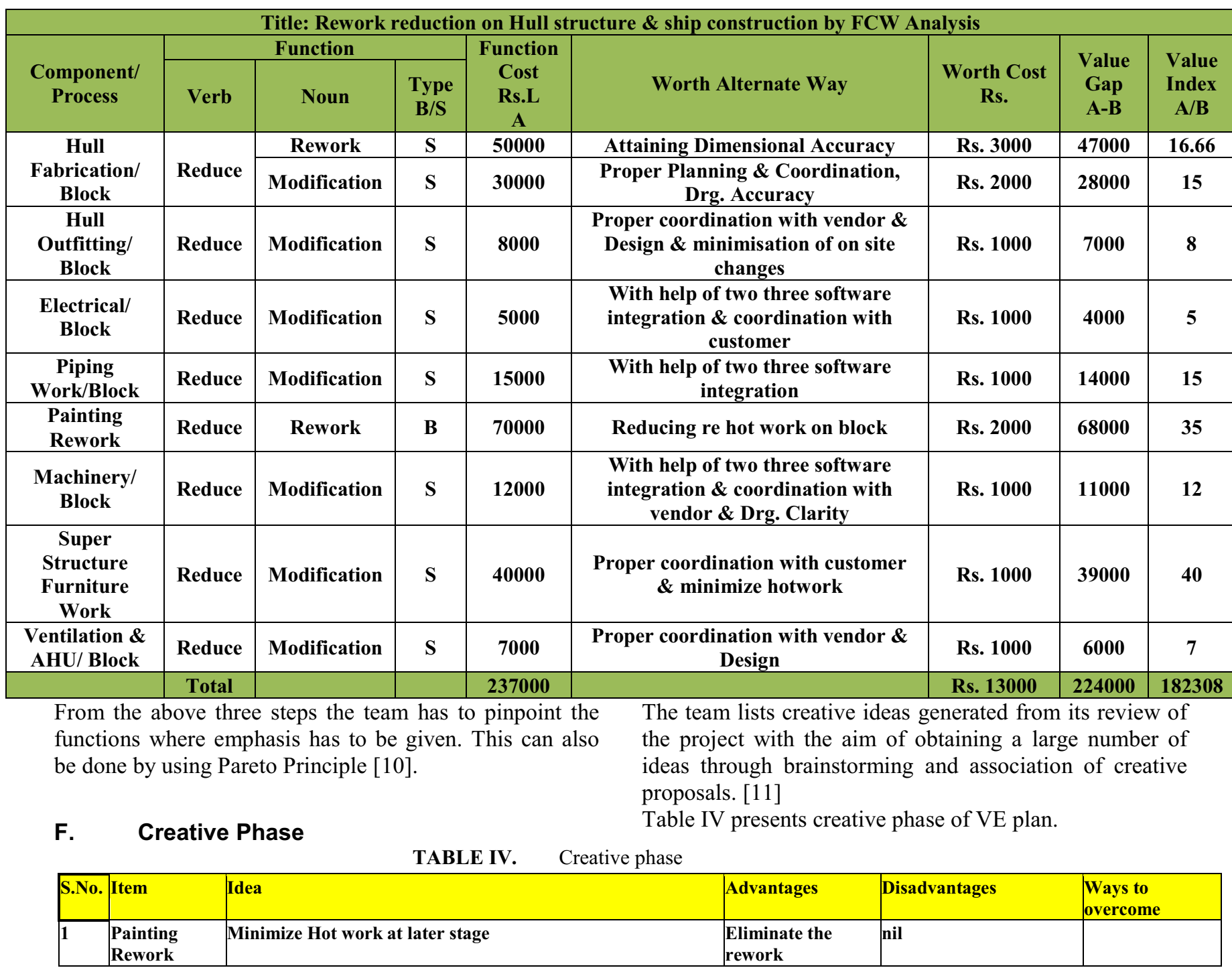


MATEC Web of Conferences

\begin{tabular}{|c|c|c|c|c|c|}
\hline & \multirow[t]{2}{*}{ Reduction } & Completion of all work before painting & $\begin{array}{l}\text { Eliminate the } \\
\text { rework }\end{array}$ & nil & \\
\hline & & Make area Blanck,where burning at later stage is anticipated. & $\begin{array}{l}\text { Eliminate the } \\
\text { rework }\end{array}$ & nil & \\
\hline \multirow[t]{4}{*}{2} & \multirow{4}{*}{\begin{tabular}{|l|} 
Hull \\
fabrication \\
Rework
\end{tabular}} & Approved production Drg. From class before issue & $\begin{array}{l}\text { Eliminate class } \\
\text { rework }\end{array}$ & $\begin{array}{l}\text { Pay additional cost for } \\
\text { approval }\end{array}$ & \\
\hline & & $\begin{array}{l}\text { Coordination \& approval system Between Hull Design, } \\
\text { Piping Design before issue Drg. }\end{array}$ & $\begin{array}{l}\text { Eliminate class } \\
\text { rework }\end{array}$ & Take more time & $\begin{array}{l}\text { Can employ } \\
\text { more resource }\end{array}$ \\
\hline & & $\begin{array}{l}\text { Introduce new software to optimise \& correcting previous } \\
\text { system Drawback }\end{array}$ & $\begin{array}{l}\text { Eliminate class } \\
\text { rework }\end{array}$ & Additional cost & \\
\hline & & Management of customer Demand at Design stage & $\begin{array}{l}\text { Eliminate class } \\
\text { rework }\end{array}$ & $\begin{array}{l}\text { Customer may not give } \\
\text { approval at design stage. }\end{array}$ & \\
\hline \multirow[t]{3}{*}{3} & \multicolumn{2}{|c|}{ Piping reworkFull kit the system before starting of work } & Fast execution & More Lead time & Proper Planning \\
\hline & & $\begin{array}{l}\text { Start the fabrication work after freezing all pipe system } \\
\text { Design. }\end{array}$ & $\begin{array}{l}\text { Reduce the routing } \\
\text { Rework }\end{array}$ & nil & \\
\hline & & Do not Entertain the Customer Demand at Later stage & $\begin{array}{l}\text { Reduce the } \\
\text { rework, extra time } \\
\text { and Cost }\end{array}$ & nil & \\
\hline \multirow[t]{2}{*}{4} & \multirow[t]{2}{*}{$\begin{array}{l}\text { Rework Due } \\
\text { Machinary }\end{array}$} & Install machinery at Block Fabrication stage & $\begin{array}{l}\text { Reduce time \& } \\
\text { labour cost }\end{array}$ & $\begin{array}{l}\text { May damage machinary } \\
\text { during further handling } \\
\text { of Block }\end{array}$ & $\begin{array}{l}\text { With help of } \\
\text { proper } \\
\text { preservation } \\
\text { procedure. }\end{array}$ \\
\hline & & $\begin{array}{l}\text { Aligment between OEM,Different design Department before } \\
\text { dispatch of Machinary }\end{array}$ & Fast execution & nil & \\
\hline \multirow[t]{5}{*}{5} & \multirow{5}{*}{$\begin{array}{l}\text { Rework Due } \\
\text { to Hull } \\
\text { outfitting,Elec } \\
\text { trical,ventilati } \\
\text { on,Prodution } \\
\text { fault }\end{array}$} & Doing full kit Before start of work & Fast execution & More Lead time & $\begin{array}{l}\text { Can employ } \\
\text { more resource }\end{array}$ \\
\hline & & $\begin{array}{l}\text { Alignment between OEM,Different design Department before } \\
\text { dispatch of Machinery }\end{array}$ & Fast execution & More recourse required & \\
\hline & & $\begin{array}{l}\text { Coordination between Production \& Different department for } \\
\text { Hot work }\end{array}$ & Reduce the rework & nil & \\
\hline & & $\begin{array}{l}\text { Well defined Job scope between different contractors to } \\
\text { known all }\end{array}$ & Reduce extra cost & nil & \\
\hline & & $\begin{array}{l}\text { Do not Entertain the Customer Demand at Production stage } \\
\text { if its time \& cost consuming }\end{array}$ & $\begin{array}{l}\text { Reduce extra cost } \\
\text { \& time }\end{array}$ & nil & \\
\hline
\end{tabular}

\section{G. Idea Comparison}

All the ideas shortlisted during the creative phase are now put to the comparison. Firstly weightage of criterion is used and then paired comparison is done for comparing these ideas [12]. Table $\mathrm{V}$ represents weightage of criterion and Table VI describes pairwise comparison.

TABLE V. Weightage of criterion

\begin{tabular}{|l|c|c|c|}
\hline \multicolumn{1}{|c|}{ Identify Criteria } & Code & Score & Rank \\
\hline Technology & A & 14 & 4 \\
\hline Development cost & B & 28 & 3 \\
\hline Probability of Implementation & C & 36 & 1 \\
\hline Time to Implement & D & 31 & 2 \\
\hline Ergonomics & E & 5 & 5 \\
\hline Savings & F & 36 & 1 \\
\hline
\end{tabular}

TABLE VI. Paired comparison

\begin{tabular}{|c|c|c|c|c|}
\hline B & $\bar{C}$ & $\bar{D}$ & $\bar{E}$ & $\bar{F}$ \\
\hline \multirow[t]{5}{*}{$\mathrm{A} A 1, \mathrm{~B} 9$} & A1,C9 & A1,D9 & A9,E1 & A1,F9 \\
\hline & B B3,C7 & B5,D5 & B9,E1 & B4,F7 \\
\hline & & C & C9,E1 & C6,F4 \\
\hline & & & $\mathrm{D} D$ D,E1 & D3,F7 \\
\hline & & & & $\mathrm{E} E 1, \mathrm{~F} 9$ \\
\hline Compare c & relative & on $1-10 \mathrm{sc}$ & & \\
\hline
\end{tabular}

\section{H. Decision Matrix}

A decision matrix is list of values in rows and columns that allow analyst to systematically identify, analyze, rate the performance of relationships for sets of values and information [13]. Table VII represents decision matrix.
TABLE VII. Decision matrix

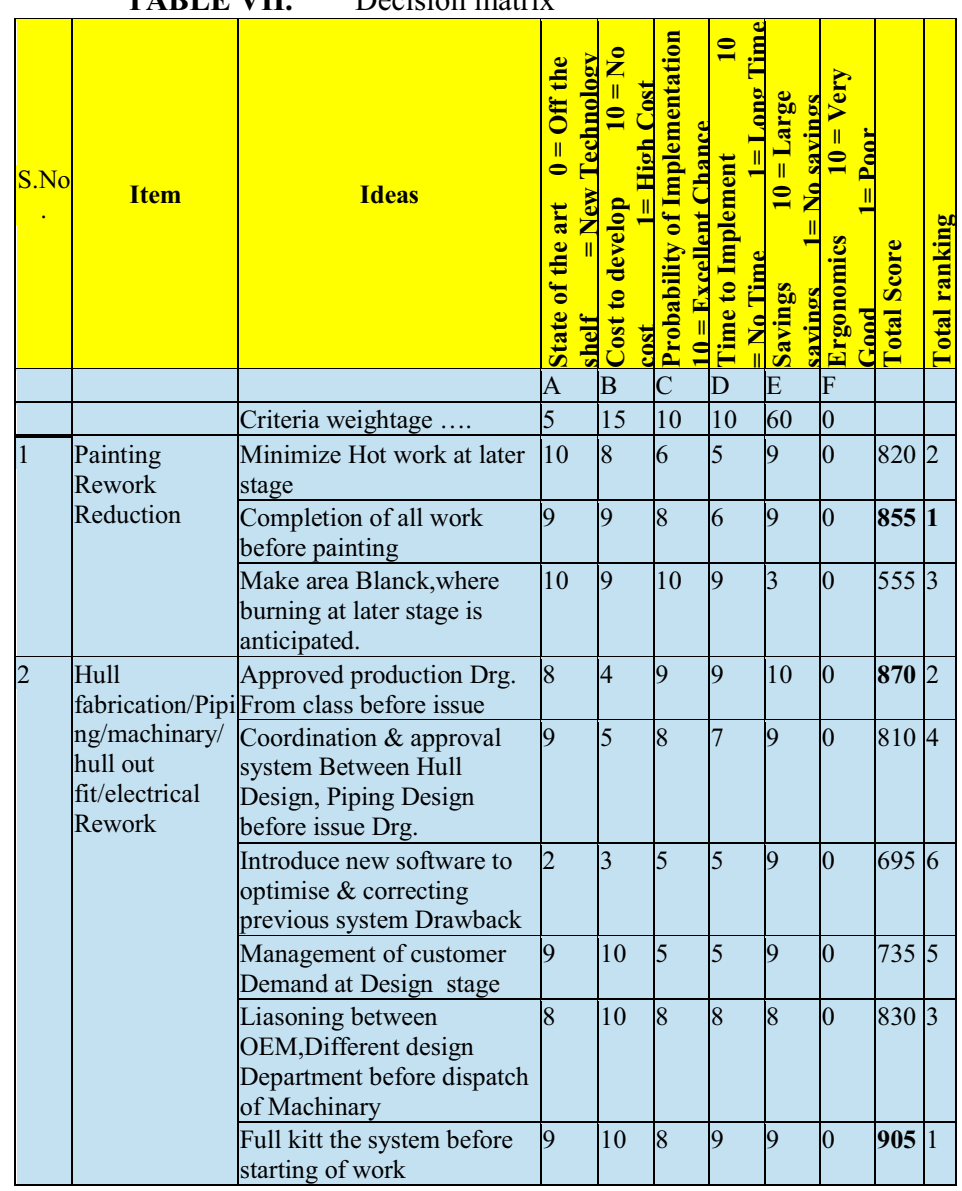

I. Development Phase 
In this phase all the included techniques are culminated and all previous efforts exerted throughout the job plan are wrapped up [14]. Table VIII represents the implementation plan.

TABLE VIII. Implementation plan

\begin{tabular}{|c|c|c|c|c|c|}
\hline \multicolumn{6}{|c|}{ Implementation Plan: VE on Reduction of rework in Hull Structure \& in Ship } \\
\hline S.No. & Activity & Resource required & Responsibility & Planned Date & Actual Date \\
\hline 1 & Presentation to BU Head/ Dept. Head/ Factory Head & & $\begin{array}{l}\text { Mr. J. L. Mehta \& } \\
\text { Mr. S. R. } \\
\text { Prajapati }\end{array}$ & 20-11-2014 & 05-12-2014 \\
\hline 2 & $\begin{array}{l}\text { Formation of team at Design Department for internal } \\
\text { coordination among them }\end{array}$ & $\begin{array}{l}\text { Design Department } \\
\text { Support }\end{array}$ & $\begin{array}{l}\text { Mr. Dinesh } \\
\text { Sidhhapura \& } \\
\text { Mr. Ajit Das } \\
\end{array}$ & 05-12-2014 & 20-12-2014 \\
\hline 3 & Full Kitting team formation in Planning Department & Planning Department & Mr. Yoon & 05-12-2014 & 20-12-2014 \\
\hline 4 & $\begin{array}{l}\text { Team formation in Project Management group to deal with } \\
\text { customer on site demand with the help of design }\end{array}$ & $\begin{array}{l}\text { Planning } \\
\text { Management Group } \\
\text { Support }\end{array}$ & $\begin{array}{l}\text { Mr. Dinesh } \\
\text { Prassad }\end{array}$ & 05-01-2015 & 20-01-2015 \\
\hline 5 & $\begin{array}{l}\text { Project Management group will also form team to finalize } \\
\text { scope of work among different Department before start of } \\
\text { Project }\end{array}$ & $\begin{array}{l}\text { Planning } \\
\text { Management Group } \\
\text { Support }\end{array}$ & $\begin{array}{l}\text { Mr. Dinesh } \\
\text { Prassad }\end{array}$ & 05-01-2015 & 20-01-2015 \\
\hline 6 & Make investment proposal for new software & Capital Cost & Mr. Ajit Das & 15-12-2014 & 30-12-2014 \\
\hline 7 & Introduce Procedure (Check List) to issue Drawing to Planning & $\begin{array}{l}\text { Design \& Planning } \\
\text { Department }\end{array}$ & Mr. Yoon & 05-01-2015 & 20-01-2015 \\
\hline 8 & $\begin{array}{l}\text { Planning will ensure checklist of items before issuing to } \\
\text { Production }\end{array}$ & Planning Department & Mr. Prassad & 05-01-2015 & 20-012015 \\
\hline & obtained & $\begin{array}{l}\text { vol. } \quad 12 \\
7863(94) 9\end{array}$ & $\begin{array}{l}\text { pp. } \\
9-4\end{array}$ & DOI: & $.1016 / 0263$ \\
\hline
\end{tabular}

\section{implementation of the project at the company}

- Product design is modified and improved.

- Efficient processes are used.

- Product cost is reduced.

- Cheaper and better materials are used.

- Product value and quality gets improved and the quest for new processes gets encouraged.

- Unnecessary rework costs in the new product (Roll Dock) are prevented.

- There is greater return on investment and greater profit is accrued due to reduction of rework, modification in product design and cycle time reduction.

\section{K. Conclusion}

The case study on Roll Dock Ship was carried out at Larsen \& Toubro Shipbuilding, Hazira, Surat, India for reducing reworks of blocks of hull structure in the ship with the help of value engineering plan. The reworks are reduced by systematic implementation of value engineering, excessive costs due to the reworks and cycle time of ship production in ship building project are reduced, which ultimately saved Rs. 78 Lakhs through implementation of value engineering project in the company.

\section{References}

1. Kim H. Pries, Jon M. Quigley, "Reducing Process Costs with Lean, Six Sigma, and Value Engineering Techniques", CRC Press, 2012.

2. Florian G. H. Behncke, S. Maisenbacher and M. Maurer, "Extended Model for Integrated Value Engineering," presented at Conference on Systems Engineering Research, CA, March 21-22, 2014, pp. 781-788. DOI: 10.1016/j.procs.2014.03.093

3. Green SD., "Beyond value engineering: SMART value management for building projects." International Journal of Project Management, 1994;
4. Webb A., "Value engineering", Engineering Management Journal. 1993, pp.171-175.

5. Del Younker, Value Engineering: Analysis And Methodology, New York, Marcel Dekker, 2003, ch. 7, pp. 32-34.

6. A. Sharma, H. Srivastava, R.M. Belokar, "A Case Study Analysis Through The Implementation of Value Engineering", International Journal Engineering Science and Technology, vol. 3, no. 3, 2011, pp. 2204-2213.

7. S.K. Sharma, S. Sharma, T. Sharma, Industrial Engineering and Operations Management, $2^{\text {nd }}$ ed. New Delhi, Kataria \& Sons, 2008, ch. 34, pp. 714 725.

8. Jay Mandelbaum, Anthony Hermes, Donald Parker, Heather Williams, "Value Engineering Synergies with Lean Six Sigma”, CRC Press, 2012, ch. 1, pp. 6-11.

9. A.K. Mukhopadhyaya, Value Engineering: Concepts, Techniques and Applications, $1^{\text {st }}$ ed. New Delhi, Response books, 2003, ch. 7, pp. 68-106.

10. Ugo Ibusuki, Paulo Carlos Kaminski, "Product development process with focus on value engineering and target-costing: A case study in an automotive company" International Journal of Production Economics, vol. 105, no. 2, pp. 459-474, 2007. DOI: 10.1016/j.ijpe.2005.08.009

11. Lawrence D. Miles, Techniques of Value Analysis and Engineering, $2^{\text {nd }}$ ed., McGraw-Hill Book Company, 1972.

12. Haskins C., Systems Engineering Handbook - A Guide for System Life Cycle Processes and Activities. 2010; pp. 3.1-3.19.

13. S.S. Iyer, Value engineering: A How to Manual, $2^{\text {nd }}$ ed., New Delhi, New Age International Publishers, 2000, ch. 2, pp. 89-171.

14. R. Paneerselavam, Engineering Economics, New Delhi, PHI Learning, 2012, ch. 15, pp. 192-198. 